\title{
Antioxidative potential of Chenopodium botrys L. (Amaranthaceae)
}

\author{
Ljubica Adji Andov ${ }^{1 *}$, Marija Karapandzova ${ }^{1}$, Blagica Jovanova ${ }^{2}$, Gjose Stefkov ${ }^{1}$, \\ Ivana Cvetkovikj Karanfilova ${ }^{1}$, Tatjana Kadifkova Panovska ${ }^{2}$ and Svetlana Kulevanova ${ }^{1}$ \\ ${ }^{1}$ Institute of Pharmacognosy, Faculty of Pharmacy, University 'Ss. Cyril and Methodius', Mother Teresa 47, \\ 1000 Skopje, R. Macedonia \\ ${ }^{2}$ Institute of Applied Biochemistry, Faculty of Pharmacy, University 'Ss. Cyril and Methodius', Mother Teresa 47, \\ 1000 Skopje, R. Macedonia
}

Received: July 2015; Accepted: September 2015

\begin{abstract}
Evaluation of the antioxidant potential of methanol extract of Chenopodium botrys L. (Amaranthaceae) collected from six different locations in Republic of Macedonia was performed. Several methods were used for testing the antioxidative activity: 1) 2,2-diphenyl1-picrylhydrazyl (DPPH) radical scavenging assay, 2) ferric reduction power assay (FRAP), 3) inhibition of $\mathrm{H}_{2} \mathrm{O}_{2}$ activity, 4) non-sitespecific hydroxyl radical-catalyzed 2-deoxy-D-ribose degradation (NSSOH) and 5) site-specific hydroxyl radical-catalyzed 2-deoxy-D-ribose degradation (SSOH). The $\mathrm{IC}_{50}$ values ranged from $0.26-3.10 \mathrm{mg} / \mathrm{mL}, 3.01-12.71 \mathrm{mg} / \mathrm{mL}$ and $2.60-12.29 \mathrm{mg} / \mathrm{mL}$, for DPPH, NSSOH and $\mathrm{SSOH}$ assays, respectively. The $\mathrm{H}_{2} \mathrm{O}_{2}$ inhibition activity and the ferric reducing power capacity were from 28.84-46.56\% and 26.14$43.40 \%$, respectively. The obtained data establish the antioxidant potency in concentration-dependent manner. Additionally, total phenols (TPC) and total flavonoid content (TFC) were determined. The estimated values ranged from 27.77-71.25 mg GAE/g DW and from 7.35$16.33 \mathrm{mg}$ QE/g DW, respectively.
\end{abstract}

Keywords: Chenopodium botrys, total flavonoids, total phenols, antioxidative activity, DPPH, NSSOH assay, SSOH assay, FRAP, $\mathrm{H}_{2} \mathrm{O}_{2}$ inhibition

\section{Introduction}

Oxidative stress plays an important role in the etiology of chronic diseases such as cancer, atherosclerosis and diabetes as well as age-related neurological degenerative disorders. In the last couple of decades, the misperception of safety chronic consumption of synthetic antioxidants has increased the interest in phytochemicals as biological antioxidants which are defined as substances present in low concentrations that can reduce or prevent oxida- tion of the easily oxidisable substrate (Shikov et al., 2006; Benzie and Strain, 1996). Among enormous variety of secondary metabolites, polyphenols have a wide range of biological activities: anti-inflammatory, antiallergenic, antioxidant and antitumor, and have an impact on improving the immune system, as well (Pasko et al., 2008). Numerous studies have demonstrated the importance of naturally occurring dietary polyphenols in promoting of cardiovascular health and emphasized the significant role these compounds play in limiting the effects of cellular aging (Khura et al., 2013). Also, they pointed to the impact of

\footnotetext{
*bube.petrovska@yahoo.com
} 
phenolic compounds on carcinogenic cells which is crucial for their antitumor potential (Boivin et al., 2009). Anticancer activity is partly attributed to the antioxidative effects of phenolic compounds and polyphenols as they are defined as reducing agents, free radical scavengers, hydrogen donors and inhibitors of pro-oxidative enzymes (GawlikDziki, 2012; Cai et al., 2004). Since, recent studies are increasingly directed towards finding new antioxidant compounds, that requires a lot of information and additional research related to antioxidative potential of natural components (Nikolova et al., 2011).

The genus Chenopodium comprises numerous members of perennial and annual species, which occur everywhere in the world. They could grow as aromatic or non-aromatic herbaceous plants or as shrubs and small trees (Fuentes-Bazan et al., 2012). C. botrys L. (syn. Dysphania botrys (L.) Mosyakin and Clemants), known as Jerusalem Oak Goosefoot or Feathered Geranium, commonly grows in Europe and is native to Mediterranean region, but it also could be found in Asia, India, Himalayas, Turkey, Cyprus, Africa, Australia and North and South America (Seidemann, 2005). The plant is known as traditional medicine for different ailments in respiratory tract, especially for the treatment of catarrh and humoral asthma, when it is used as a substitute for C. ambrosioides (Yadav et al., 2007). Concerning literature data, C. botrys contains flavonoids, alkaloids, terpenes and essential oil (Kokanova-Nedialkova et al., 2009). Regarding this, pharmacological analyses confirm medical potential of $C$. botrys in the development of new drugs. Various isomers of specific monoterpene compound, ascaridole, were identified in $C$. botrys oil which was associated with the activity against various tumor cell lines in vitro (Morteza-Semnani, 2015). Additionally, in the aerial parts of C. botrys, the flavon chrysoeriol as well as flavonoids: salvigenin, sinensetin, hispidulin, quercetin and their derivatives were identified, which were related to a potential antioxidant activity (Kokanova-Nedialkova et al., 2009).

In the flora of the Republic of Macedonia (RM), 15 species of the genus Chenopodium occur naturally, including C. botrys (Micevski, 1995). Dried over ground flowering parts of the plant (herba) are utilized by local people for preparing infusions or liquid extracts with diuret- ic, antispasmodic, carminative and antidiarrheal properties (Maksimovic et al., 2005). Despite its usage, chemical composition and biological activity of this plant are poorly known. Therefore, the aim of this study was determination of the total phenolic and total flavonoid content as well as evaluation of the antioxidant capacity of C. botrys collected from different localities of the Republic of Macedonia (RM).

\section{Experimental}

\section{Plant material}

The aerial parts of $C$. botrys were collected in the period from July to September in 2012, 2013 and 2014 at six localities in RM (Table 1). Plant identity was verified and a herbarium voucher specimen (NoCB1/12; NoCB1/13 and NoCB1/14) was deposited at the Department of Pharmaceutical Botany, Institute of Pharmacognosy, Faculty of Pharmacy, University 'Ss. Cyril and Methodius', Skopje, R. Macedonia. Collected plant material was air-dried and preserved in paper bags until performing the analysis, when it was properly milled and homogenised.

\section{Chemicals and standards}

Folin-Ciocalteu reagent, Gallic acid, Aluminum chloride and Quercetin were purchased from Merck (Darmstadt, Germany), Sodium carbonate, Sodium nitrite, Ascorbic acid, Butylated hydroxyanisole (BHA) and Sodium hydroxide from Alkaloid (Skopje, R. Macedonia), while Methanol was purchased from Carlo Erba (Milano, Italy).

\section{Extract preparation}

$2.5 \mathrm{~g}$ of dried and fine grounded plant material was extracted in ultrasonic bath $(50 / 60 \mathrm{~Hz}, 720 \mathrm{~W})$ at room temperature, twice with $15 \mathrm{~mL}$ of $100 \%$ methanol (HPLC grade), each time for $15 \mathrm{~min}$. After filtration, the volume was made up to $25 \mathrm{~mL}$ with methanol. Obtained methanol extracts $(0.1 \mathrm{~g} / \mathrm{mL})$ were used for determination of total phenols and total flavonoids and for evaluation of the

Table 1: Plant material of C. botrys

\begin{tabular}{|c|c|c|c|c|}
\hline No. & Sample & Locality & Geographical position in RM & Year of harvesting \\
\hline 1. & CB1/12 & Kozuf Mtn. & Southeast & 2012 \\
\hline 2. & $\mathrm{CB} 2 / 13$ & Pretor & Southwest & 2013 \\
\hline 3. & $\mathrm{CB} 3 / 14$ & Strumica & Southeast & 2014 \\
\hline 4. & CB4/14 & Zletovo & East & 2014 \\
\hline 5. & CB5/13 & Radovis & East & 2013 \\
\hline 6. & $\mathrm{CB} 6 / 14$ & Stip & East & 2014 \\
\hline
\end{tabular}


antioxidant activity.

\section{Determination of total phenolic content (TPC)}

TPC was determined with the Folin-Ciocalteu reagent according to a procedure described by Singleton et al., (1999) with slight modifications. Folin-Ciocalteu reagent $(2.5 \mathrm{~mL}, 1: 10 \mathrm{v} / \mathrm{v}$ diluted with distilled water) was added to the test sample $(0.1 \mathrm{~mL}$ methanol extract), and stirred for $5 \mathrm{~min}$ at room temperature. Subsequently, $3 \mathrm{~mL}$ of $7 \%$ sodium carbonate was added and made up to $10 \mathrm{~mL}$ with distilled water. This mixture was incubated at room temperature in dark place for $1 \mathrm{~h}$. After incubation, absorbance of blue color was measured at $765 \mathrm{~nm}$ using a Agilent 8453 UV-Vis spectrophotometer. The total phenolic content was estimated as mg of gallic acid equivalents (GAE) per gram of dried weight of plant material (mg GAE/g DW) using an equation obtained from standard gallic acid calibration curve.

\section{Determination of total flavonoid content (TFC)}

TFC was determined using the Aluminum chloride assay described by Lallianrawna et al., (2013). An aliquot of the test sample $(0.1 \mathrm{~mL}$ methanol extract) was mixed with $0.1 \mathrm{~mL}$ of $5.0 \%$ sodium nitrite and allowed to stand for $5 \mathrm{~min}$. Then, $0.15 \mathrm{~mL}$ of $10.0 \%$ aluminum chloride were added to the mixture, kept at room temperature for six more minutes and followed by the addition of $0.5 \mathrm{~mL}$ of 1 $\mathrm{M}$ sodium hydroxide. The total volume was made up to 2.5 $\mathrm{mL}$ with distilled water. The resulting solution was mixed well and the absorbance was measured immediately at 510 nm using an Agilent $8453 \mathrm{UV}$-Vis spectrophotometer. The blank was prepared by replacing the extracts with an equal volume of deionized water. The TFC was expressed as $\mathrm{mg}$ of quercetin equivalents (QE) per gram of dried weight of plant material (mg QE/g DW) using an equation obtained from standard quercetin calibration curve.

\section{Free radical scavenging activity (DPPH assay)}

The scavenging activity of DPPH free radicals of $C$. botrys extracts was done according the method reported by Kurin et al.,(2012) with minor modifications. $200 \mu \mathrm{L}$ of different concentrations of tested samples (100, 50 and $20 \mathrm{mg} / \mathrm{mL}$ ) were transferred in a cuvette and $4 \mathrm{~mL}$ of 100 $\mu \mathrm{M}$ ethanol solution of DPPH radical were added. Mixtures were shaken vigorously for one min and left to stand $10 \mathrm{~min}$ in dark place at room temperature. The reduction of the DPPH free radicals was measured by reading the absorbance at $517 \mathrm{~nm}$ on final concentrations of extracts in the reaction mixture (1.0, 2.5 and $5.0 \mathrm{mg} / \mathrm{mL})$. Methanol was used as control blank. Quercetin and BHA were used as standards, with final concentrations in the reaction mixture of $0.0005,0.001$ and $0.0025 \mathrm{mg} / \mathrm{mL}$. The antioxidant capacity of methanol extracts was expressed as $\mathrm{IC}_{50}$ val- ues (extract concentration providing $50 \%$ of radical scavenging activity) that were calculated by interpolation from the graph obtained by plotting the percentage of inhibition against extract concentration.

\section{Ferric reducing antioxidant power (FRAP)}

The ferric reducing power of $C$. botrys methanol extracts was determined by using the Potassium ferricyanide/ferric chloride assay reported by Shahat et al. with minor modifications [23]. Different concentrations of extracts $(100,50$ and $20 \mathrm{mg} / \mathrm{mL})$ were added to $2.5 \mathrm{~mL}$ of $0.2 \mathrm{M}$ phosphate buffer ( $\mathrm{pH} 6.6$ ) and $2.5 \mathrm{~mL}$ of $1 \%$ potassium ferricyanide. The mixtures were incubated at $50{ }^{\circ} \mathrm{C}$ for $20 \mathrm{~min}$, after which $2.5 \mathrm{~mL}$ of $10 \%$ trichloroacetic acid was added. An aliquot of the mixture $(2.5 \mathrm{~mL})$ was taken and mixed with $2.5 \mathrm{~mL}$ water and $0.5 \mathrm{~mL} 1 \% \mathrm{FeCl}_{3}$. After $30 \mathrm{~min}$, the absorbance was measured at $700 \mathrm{~nm}$ on the final concentrations of extracts in the reaction mixture $(2.8$ $\mathrm{mg} / \mathrm{mL}$ ). Quercetin and ascorbic acid were used as standards with final concentrations in the reaction mixture of $0.007 \mathrm{mg} / \mathrm{mL}$. The ferric reducing antioxidant power was expressed in percentage $(\%)$ after construction of $\mathrm{FeSO}_{4} \mathrm{x}$ $7 \mathrm{H}_{2} \mathrm{O}$ calibration curve. Higher absorbance of the reaction mixture indicated greater reducing power.

\section{$\mathrm{H}_{2} \mathrm{O}_{2}$ inhibition effect}

The $\mathrm{H}_{2} \mathrm{O}_{2}$ inhibition effect of $C$. botrys extracts was determined according to the method reported by Serteser et al., (2009). One $\mathrm{mL}$ of extract $(100 \mathrm{mg} / \mathrm{mL}), 3.4 \mathrm{~mL}$ of $0.1 \mathrm{M}$ phosphate buffer $(\mathrm{pH} \mathrm{7.4)}$ and $0.6 \mathrm{~mL}$ of $43 \mathrm{mM}$ $\mathrm{H}_{2} \mathrm{O}_{2}$ were mixed and after 60 minutes the absorbance of the mixture with final concentrations of extracts $(20 \mathrm{mg} /$ $\mathrm{mL}$ ) in the reaction mixture was measured at $230 \mathrm{~nm}$. Controls without $\mathrm{H}_{2} \mathrm{O}_{2}$ were prepared for each sample concentration. To determine the $\mathrm{H}_{2} \mathrm{O}_{2} \mathrm{mM}$ concentration that did not involve the reaction, a linear regression equation was used. $3.4 \mathrm{~mL}$ of phosphate buffer were added to $0.6 \mathrm{~mL}$ of $10,15,25,43$ and $50 \mathrm{mM} \mathrm{H}_{2} \mathrm{O}_{2}$ and the absorbance was measured at $230 \mathrm{~nm}$. Linear regression equations were obtained by the diagram of concentration against absorbance. Quercetin was used as standard solution. The percentage of inhibition was calculated from the $\mathrm{H}_{2} \mathrm{O}_{2}$ concentration of control and $\mathrm{H}_{2} \mathrm{O}_{2}$ concentration of sample using the following equation:

$\mathrm{H}_{2} \mathrm{O}_{2}$ inhibition capacity $(\%)=\left[1-\left(\frac{\mathrm{H}_{2} \mathrm{O}_{2} \text { conc. of sample }}{\mathrm{H}_{2} \mathrm{O}_{2} \text { conc. of control }}\right)\right] \times 100$

\section{Nonsite-Specific Hydroxyl Radical-Mediated 2-Deoxy-D-} Ribose Degradation (NSSOH)

Inhibition of nonsite-specific hydroxyl radical-mediated degradation was carried out according to Halliwell et 
al., (1987) with slight adaptations. The reaction mixture contained $100 \mu \mathrm{L}$ of methanol extract, $500 \mu \mathrm{L}$ 2-Deoxy-Dribose (5.6 mM, in $\mathrm{KH}_{2} \mathrm{PO}_{4}-\mathrm{NaOH}$ buffer, $\left.\mathrm{pH} 7.4\right), 200 \mu \mathrm{L}$ premixed $(1: 1 \mathrm{v} / \mathrm{v}) \mathrm{FeCl}_{3}(100 \mu \mathrm{M})$ and EDTA $(104 \mu \mathrm{M})$, $100 \mu \mathrm{L} \mathrm{H}_{2} \mathrm{O}_{2}(1.0 \mathrm{mM})$ and $100 \mu \mathrm{L}$ ascorbic acid (1.0 mM). After vortexing and $30 \mathrm{~min}$ incubation at $50{ }^{\circ} \mathrm{C}$, trichloroacetic acid $(1 \mathrm{~mL}, 2.8 \%)$ and thiobarbituric acid $(1 \mathrm{~mL}$, $1.0 \%$ ) were added. The mixture was vortexed and heated at $50{ }^{\circ} \mathrm{C}$ for 30 more minutes. The extent of oxidation was estimated from the solution absorbance of the final concentrations of extracts in the reaction mixture $(0.6,1.6$ and 3.3 $\mathrm{mg} / \mathrm{mL}$ ) at $532 \mathrm{~nm}$. Quercetin and BHA were used as standards with final concentrations in the reaction mixture of $0.6,1.6$ and $3.3 \mu \mathrm{g} / \mathrm{mL}$. $\mathrm{IC}_{50}$ values were estimated using linear regression of the linear part of the curve.

\section{Site-Specific Hydroxyl Radical-Mediated 2-Deoxy-D-ri- bose Degradation (SSOH)}

Inhibition of site-specific hydroxyl radical-mediated 2-deoxy-D-ribose degradation was measured according to Halliwell et al., (1987) with slight adaptations. The reaction mixture contained $100 \mu \mathrm{L}$ of methanol extract, $500 \mu \mathrm{L}$ 2-Deoxy-D-ribose (5.6 mM in $\mathrm{KH}_{2} \mathrm{PO}_{4}-\mathrm{NaOH}$ buffer, $\mathrm{pH}$ 7.4), $100 \mu \mathrm{L} \mathrm{FeCl}_{3}(100 \mu \mathrm{M}), 100 \mu \mathrm{L} \mathrm{KH}_{2} \mathrm{PO}_{4}-\mathrm{NaOH}$ buffer (pH 7.4), $100 \mu \mathrm{L} \mathrm{H}_{2} \mathrm{O}_{2}(1.0 \mathrm{mM})$ and $100 \mu \mathrm{L}$ ascorbic acid $(1.0 \mathrm{mM})$. After vortexing and $30 \mathrm{~min}$ incubation at $50{ }^{\circ} \mathrm{C}$, trichloroacetic acid $(1 \mathrm{~mL}, 2.8 \%)$ and thiobarbituric acid $(1 \mathrm{~mL}, 1.0 \%)$ were added. The mixture was vortexed and heated at $50{ }^{\circ} \mathrm{C}$ for $30 \mathrm{~min}$. The extent of oxidation was estimated from the solution absorbance of the final concentrations of extracts in the reaction mixture $(0.6,1.6$ and 3.3 $\mathrm{mg} / \mathrm{mL}$ ) at $532 \mathrm{~nm}$. Quercetin and BHA were used as standards with final concentrations in the reaction mixture of $0.6,1.6$ and $3.3 \mu \mathrm{g} / \mathrm{mL}$. $\mathrm{IC}_{50}$ values were estimated using linear regression of the linear part of the curve.

\section{Statistical analysis}

Data obtained from determination of TPC and TFC were expressed as mean values $\pm \mathrm{SD}$ as all experiments were carried out in triplicate. Statistical analyses were performed by statistical package STATGRAPH 21.0. The $p$ value less than 0.05 was considered to be statistically significant.

\section{Results and discussion}

\section{Total phenolic and total flavonoids content}

The $C$. botrys samples analysed in this study showed presence of total phenolic content in range of 27.77 to 71.25 $\mathrm{mg}$ of gallic acid equivalents per gram of dried weight of plant material (mg GAE/g DW), for samples from Stip (CB6/14) and Pretor (CB2/13), respectively (Table 2).
Table 2. Total phenolic and flavonoid content in C. botrys

\begin{tabular}{lcc}
\hline \hline Sample Locality & $\begin{array}{c}\text { Total phenolics } \\
(\mathrm{mg} \text { GAE/g DW } \pm \text { SD) }\end{array}$ & $\begin{array}{c}\text { Total flavonoids } \\
\text { QE/g DW } \pm \text { SD) }\end{array}$ \\
\hline CB1/12 Kozuf & $47.08 \pm 2.95$ & $16.33 \pm 0.84$ \\
CB2/13 Pretor & $71.25 \pm 4.70$ & $9.34 \pm 1.68$ \\
CB3/14 Strumica & $51.28 \pm 0.41$ & $7.69 \pm 0.36$ \\
CB4/14 Zletovo & $35.61 \pm 0.10$ & $8.52 \pm 1.81$ \\
CB5/13 Radovis & $28.42 \pm 5.63$ & $7.35 \pm 1.25$ \\
CB6/14 Stip & $27.77 \pm 0.31$ & $11.91 \pm 3.20$ \\
\hline
\end{tabular}

The quantitative analysis of total flavonoid content in different samples of $C$. botrys revealed values of TFC from 7.35 to $16.33 \mathrm{mg}$ quercetin equivalents per gram of dried weight of plant material ( $\mathrm{mg} \mathrm{QE} / \mathrm{g} \mathrm{DW}$ ) in samples from Radovis (CB5/13) and Kozuf (CB1/12), respectively (Table 2).

In the available literature, there is no data about the $C$. botrys TPC and TFC, thus only few articles could be found related to the total phenolic and total flavonoid content of other Chenopodium species. Few authors reported that $C$. album herb extracts contained $3.36 \mathrm{mg} / \mathrm{g}$ DW of free polyphenols (Nowak et a., 2015), while leaves of C. album comprised $44.2 \mu \mathrm{g} \mathrm{GAE} / \mathrm{mg}$ of total phenolics and $9.53 \mu \mathrm{g}$ $\mathrm{CE} / \mathrm{mg}$ of flavonoids (catechins) (Dasgupta and De, 2007).

\section{DPPH radical scavenging activity}

The methanol extract of $C$. botrys showed DPPH radical scavenging activity with $\mathrm{IC}_{50}$ values from $0.26-3.10$ $\mathrm{mg} / \mathrm{mL}$ (Table 3 ). The radical scavenging ability of methanol extracts was compared to the scavenging activity of two reference substances, quercetin and BHA. The estimated $\mathrm{IC}_{50}$ values were incomparably lower $(1.0 \mu \mathrm{g} / \mathrm{mL}$ and $6.0 \mu \mathrm{g} / \mathrm{mL}$, respectively). The highest DPPH scavenging activity showed the methanol extract prepared from samples from Strumica (CB3/14).

\section{Non-site-specific hydroxyl radical-catalyzed 2-deoxy-D- ribose degradation (NSSOH)}

In the method with 2-deoxy-D-ribose as a substrate, hydroxyl radicals $(\mathrm{OH} \bullet)$ are generated in conditions when EDTA-chelated iron (III) ions are incubated at physiological $\mathrm{pH}$ with reducing agent and $\mathrm{H}_{2} \mathrm{O}_{2}$. These hydroxyl radicals are capable to transfer on substrate and to fragment it into thiobarbituric acid reactive substances (TBARS). An extract that inhibits the development of TBARS in this system can be considered capable for scavenging hydroxyl radicals, protecting the carbohydrates from oxidative degradation (Shikov et al., 2006). C. botrys methanol extract has shown capability of inhibiting the formation of TBARS in a concentration-dependent manner with $\mathrm{IC}_{50}$ values from 3.01 to $12.71 \mathrm{mg} / \mathrm{mL}$. According the estimated values, extracts from samples collected from Strumica $(\mathrm{CB} 3 / 14)$ and 
Table 3: Antioxidant activity of methanol extracts of $C$. botrys

\begin{tabular}{|c|c|c|c|c|c|}
\hline Sample & $\begin{array}{c}\text { DPPH assay } \\
\mathrm{IC}_{50}(\mathrm{mg} / \mathrm{mL})\end{array}$ & $\begin{array}{l}\text { NSSOH assay } \\
\mathrm{IC}_{50}(\mathrm{mg} / \mathrm{mL})\end{array}$ & $\begin{array}{l}\text { SSOH assay } \\
\mathrm{IC}_{50}(\mathrm{mg} / \mathrm{mL})\end{array}$ & $\begin{array}{l}\text { FRAP assay } \\
(\%)\end{array}$ & $\begin{array}{c}\mathrm{H}_{2} \mathrm{O}_{2} \text { inhibition } \\
\text { Capacity assay (\%) }\end{array}$ \\
\hline CB1/12 & 1.99 & 6.83 & 4.81 & 26.98 & 36.20 \\
\hline CB2/13 & 0.95 & 3.01 & 2.60 & 43.37 & 36.22 \\
\hline CB3/14 & 0.26 & 6.05 & 4.06 & 43.40 & 36.73 \\
\hline CB4/14 & 2.10 & 10.27 & 9.97 & 30.28 & 28.84 \\
\hline $\mathrm{CB} 5 / 13$ & 1.76 & 12.37 & 10.38 & 26.14 & 31.89 \\
\hline CB6/14 & 3.10 & 12.71 & 12.29 & 30.82 & 46.56 \\
\hline Quercetin & $1.00^{*}$ & 0.29 & $6.39 *$ & $21.37 * *$ & $64.89^{* *}$ \\
\hline BHA & $6.00 *$ & 0.29 & $7.10^{*}$ & - & - \\
\hline Ascorbic acid & - & - & - & $27.71 * *$ & - \\
\hline
\end{tabular}

${ }^{*} \mu \mathrm{g} / \mathrm{mL}$

** initial concentration of ascorbic acid and quercetin $0.25 \mathrm{mg} / \mathrm{mL}$

Pretor (CB2/13) have shown better radical scavenging activity compared to samples from other localities (Table 3). The antioxidant activity of quercetin and BHA was significantly higher in comparison to the activity of the tested samples $\left(\mathrm{IC}_{50}\right.$ values were $0.29 \mathrm{mg} / \mathrm{mL}$ for both standards).

Site-specific hydroxyl radical-catalyzed 2-deoxy-D-ribose degradation ( $\mathrm{SSOH}$ )

In the site-specific hydroxyl radical-mediated 2-deoxy-D-ribose assay, an extract that inhibits the formation of TBARS in this system does not scavenge hydroxyl radicals but prevents their formation by chelating and deactivating iron (III) ions. Thus, the experiment is performed without EDTA (Shikov et al., 2006). The methanol extract of $C$. botrys was capable for preventing hydroxyl radical mediated oxidative degradation of 2-deoxy-D-ribose at physiological $\mathrm{pH}$, with $\mathrm{IC}_{50}$ values from 2.60 to $12.29 \mathrm{mg} /$ $\mathrm{mL}$. The extracts from the samples of $C$. botrys collected from Strumica (CB3/14) and Pretor (CB2/13) have shown the most prominent activity (Table 3 ). The antioxidant activity of quercetin and BHA was significantly higher, with $\mathrm{IC}_{50}$ values $6.39 \mu \mathrm{g} / \mathrm{mL}$ and $7.10 \mu \mathrm{g} / \mathrm{mL}$, respectively.

\section{FRAP assay}

Ferric reduction is often used as an indicator of electron-donating activity, which is an important mechanism of phenolic antioxidant action. The initial concentration of C. botrys methanol extract $(100 \mathrm{mg} / \mathrm{mL})$ showed ferric reducing power from $26.14-43.40 \%$ (Table 3). The extract of $C$. botrys collected from Pretor (CB2/13) and Strumica (CB3/14) have shown better activity than other samples. The reducing power of methanol extracts was compared to the activity of quercetin and ascorbic acid. These substances with initial concentration of $0.25 \mathrm{mg} / \mathrm{mL}$ showed $21.37 \%$ and $27.71 \%$ of reducing potential of ferric ions, respectively.

\section{$\mathrm{H}_{2} \mathrm{O}_{2}$-inhibition activity}

Reactive oxygen hydroxyl radical can be formed by Fenton reaction, in the presence of metal ions and $\mathrm{H}_{2} \mathrm{O}_{2}$. Indirect neutralization of resulting hydroxyl radical by $\mathrm{H}_{2} \mathrm{O}_{2}$-inhibition activity is a significant method for the determination of antioxidant activity. Scavenging of $\mathrm{H}_{2} \mathrm{O}_{2}$ by extracts may be attributed to their phenolic compounds, which can donate electrons to $\mathrm{H}_{2} \mathrm{O}_{2}$, thus neutralizing it to water (Ebrahimzadeh et al., 2010). The estimated percentages of inhibition showed that methanol extract of $C$. botrys was capable of scavenging hydrogen peroxide in a concentration dependent manner. $\mathrm{H}_{2} \mathrm{O}_{2}$-inhibition activity ranged from 28.84 to $46.56 \%$. The extracts with initial concentration of $100 \mathrm{mg} / \mathrm{mL}$ prepared from C. botrys samples from Strumica (CB3/14) and Pretor (CB2/13) showed the highest $\mathrm{H}_{2} \mathrm{O}_{2}$ inhibition ( $36.73 \%$ and $46.56 \%$, respectively) but lower potential than quercetin $(64.89 \%)$ with the initial concentration of $0.25 \mathrm{mg} / \mathrm{mL}$ (Table 3).

In the present study, the evaluation of the antioxidant activity of methanol extracts of $C$. botrys was tested by methods that involve different biochemical mechanisms: DPPH radical scavenging activity, ferric reducing power determination (FRAP), $\mathrm{H}_{2} \mathrm{O}_{2}$-inhibition activity and inhibition of non-site-specific and site-specific hydroxyl radical-catalyzed 2-deoxy-D-ribose degradation. All examined extracts showed activity in each performed assay in concentration-dependent manner, with better antioxidant activity in higher concentrations. The methanol extracts of $C$. botrys from Strumica (CB3/14) and Pretor (CB2/13) have shown better activity in all assays, as they have lower $\mathrm{IC}_{50}$ values in DPPH, NSSOH and SSOH assays, and higher inhibition percentage in FRAP and $\mathrm{H}_{2} \mathrm{O}_{2}$-inhibition activity assays (Fig. 1).

Comparing the obtained results for the antioxidant activity to additionally determined TPC and TFC, positive correlation can be found for the most samples of C. botrys, especially for samples collected from Pretor and Strumi$\mathrm{ca}$, as they contained the highest TPC (71.25 and $51.28 \mathrm{mg}$ GAE/g DW, in CB2/13 and CB3/14, respectively). However, the content of TFC cannot be correlated, as the sam- 

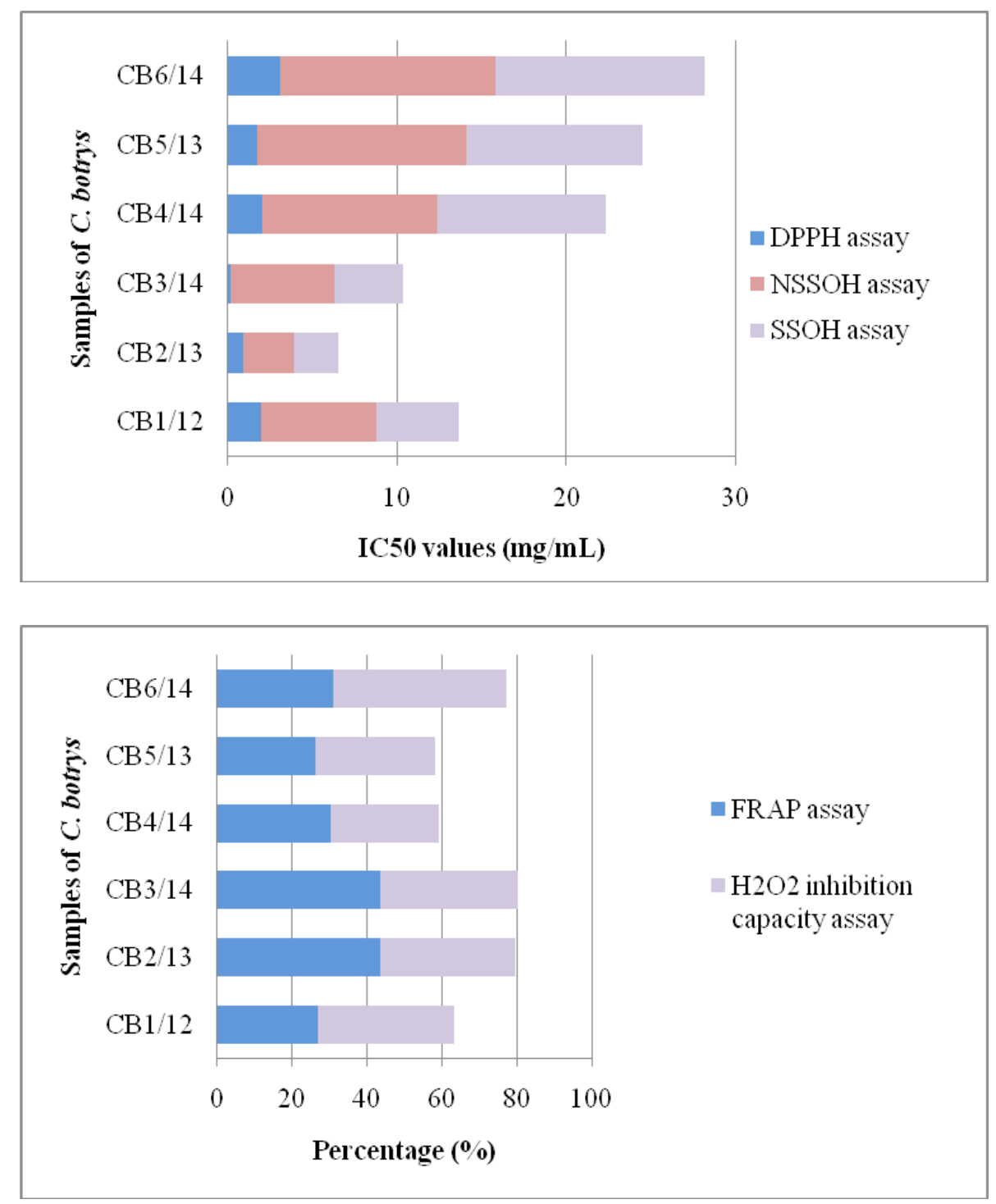

Fig. 1. Comparison of antioxidative activity of methanol extract of $\boldsymbol{C}$. botrys obtained by different antioxidative assays.

ples that contained the highest amounts of TFC did not act as the best antioxidant agents.

Positive correlation of antioxidant activity with higher TPC was previously reported. Thus, for Marrubium peregrinum L. (Lamiaceae), high content of phenolic compounds as well as significant linear correlation between their concentration values and antioxidant activity indicated that these compounds contributed to the strong antioxidant activity (Stankovic, 2011). Total phenolic and flavonoid contents showed positive correlations with the DPPH radical scavenging activity $(\mathrm{p}<0.01)$ and negative correlations with $\mathrm{IC}_{50}(\mathrm{p}<0.01)$ for methanol extracts of four Ulva species (Farasat et al., 2014). The extracts of Inula viscose showed significant antioxidant activity as the plant contained considerable levels of phenols. The ethanol extract $(0.3 \mathrm{mg} / \mathrm{mL})$ showed a remarkable antioxidant activity in three systems of assays (against 2,2-diphenyl-1-pic- rylhydrazyl, total antioxidant capacity and iron-reducing capacity), which was probably due to its high content of polyphenols (274.39 $\pm 6.94 \mathrm{mg} \mathrm{GAE} / \mathrm{g}$ dry extract) (Chahmi et al., 2015).

Since phenols are generally responsible for antioxidant activity of plant extracts, in almost all cases, the antioxidant activity followed the total phenolic content. That was proven by estimation of the correlation coefficient between the total phenolic content and antioxidant activity by Kopjar et al., (2009). The correlation coefficients between the parameters of interest ranged from 0.5749 to 0.9604 . A positive relationship between TEAC (Trolox equivalent antioxidant capacity), $\mathrm{ABTS}^{+}\left(2,2^{\prime}\right.$-azinobis[3-ethylbenzthiazoline]-6-sulfonic acid radical) and FRAP values and total phenolic content, measured by HPLC, was found in many representative herbs within Lamiaceae and Asteraceae families, as well (Wojdylo et al., 2007). Finally, con- 
tribution of the phenolics (catechin gallate, catechin, vanillic acid, kaempferol, ferulic acid, quercetin, resorcinol and 4-methylresorcinol) to the TAC (total antioxidant capacity) value indicated that phenolics (resorcinol) remarkably forwarded to the antioxidant capacity of the water-soluble extract of Chenopodium pallidicaule. This plant is considered as a potential source of natural antioxidants and other bioactive compounds which can be important for human health (Penarrieta et al., 2008).

\section{Conclusion}

Methanol extract of several specimens of Chenopodium botrys (Amaranthaceae), collected from different regions of the territory of Republic of Macedonia, showed scavenging activity against DPPH radical as well as antioxidant activity in non-site specific and site-specific hydroxyl radical catalyzed 2-deoxy-D-ribose degradation. The extracts exhibited inhibition of ferric reduction power (FRAP assay) and in $\mathrm{H}_{2} \mathrm{O}_{2}$ activity as well. In comparison to the antioxidant activity of the reference substances (quercetin, BHA and ascorbic acid) the antioxidant activity of $C$. botrys methanol extracts was consider as very poor, despite the relatively high content of total phenols and total flavonoids.

\section{References}

Benzie, I.F., Strain, J.J., 1996. The ferric reducing ability of plasma (FRAP) as a measure of "antioxidant power: the FRAP assay". Anal. Biochem. 239, 70-76.

Boivin, D., Lamy, S., Lord-Dufour, S., Jackson, J., Beaulieu, E., Côté, M., Moghrabi, A., Barrette, S., Gingras, D, Béliveau R. 2009. Antiproliferative and antioxidant activities of common vegetables: A comparative study. Food Chem. 112, 374-380.

Cai, Y., Luo, Q., Sun, M., Corke, H., 2004. Antioxidant activity and phenolic compounds of 112 traditional Chinese medicinal plants associated with anticancer. Life Sc. 74, 2157-2184.

Chahmi, N., Anissi, J., Jenna, S., Farah, A., Sendide, K., El, Hassouni, 2015. Antioxidant activities and total phenol content of Inula viscose extracts selected from three regions of Morocco. Asian Pac. J. Trop. Biomed. 5, 228-233.

Dasgupta, N., De, B., 2007. Antioxidant activity of some leafy vegetables of India: A comparative study. Food Chem. 101, 471-474.

Ebrahimzadeh, M.A., Nabavi, S.M., Nabavi, S.F., Bahramian, F., Bekhradnia, A.R., 2010. Antioxidant and free radical scavenging activity of $H$. officinalis L. var. angustifolius, $V$. odorata, B. hyrcana and C. speciosum. Pak. J. Pharm. Sci. 23, 29-34.

Farasat, M., Khvara-Nejad, R.A., Nabavi, S.M., Namjooyan, F., 2014. Antioxidant Activity, Total Phenolics and Flavonoid Contents of some Edible Green Seaweeds from Northern Coasts of the Persian Gulf. Iran. J. Pharm. Res. 13, 163-170.

Fuentes-Bazan, S., Uotila, P., Borsch, T., 2012. A novel phylogeny-based generic classification for Chenopodium sensu lato, and a tribal rearrangement of Chenopodioideae
(Chenopodiaceae). Willdenowia-Annals of the Botanic Garden and Botanical Museum Berlin-Dahlem, 42, 5-24.

Gawlik-Dziki, U., 2012. Changes in the antioxidant activities of vegetables as a consequence of interactions between active compounds. J. Funct. Foods 4, 872-882.

Halliwell, B., Gutteridge, J.M.C., Aruoma, O., 1987. The deoxyribose method: A simple "test tube" assay for determination of rate constants for reactions of hydroxyl radicals. Anal. Biochem. 165, 215-219.

Khurana, S., Venkataraman, K., Hollingsworth, A., Piche, M., Tai, T.C., 2013. Polyphenols: Benefits to the Cardiovascular System in Health and in Aging. Nutrients 5, 3779-3827.

Kokanova-Nedialkova, Z., Nedialkov, P.T., Nikolov, S.D., 2009. The genus Chenopodium: Phytochemistry, ethnopharmacology and pharmacology. Pharmacogn. Rev. 3, 280-306.

Kopjar, M., Pilizota, V., Hribar, J., Simcic, M., 2009. Total phenol content and antioxidant activity of water solutions of plant extracts. Croatian J. Food Sci. Tech. 1, 1.

Kurin, E., Mucaji, P., Nagy, M., 2012. In vitro antioxidant activities of three red wine polyphenols and their mixtures: an interaction study. Molecules 17, 14336-14348.

Lallianrawna, S., Muthukumaran, R., Ralte, V., Gurusubramanian, G., Kumar, N.S., 2013. Determination of total phenolic content, total flavonoid content and total antioxidant capacity of Ageratina adenophora (Spreng.) King \& H. Rob. Science vision, 13, 149-156.

Maksimović, Z.A., Đorđević, S., Mraović, M., 2005. Antimicrobial activity of Chenopodium botrys essential oil, Fitoterapia 76, 112-114.

Micevski, K., 1995. Flora of the Republic of Macedonia. Macedonian Academy of Science and Art, Skopje, Republic of Macedonia.

Morteza-Semnani, K., 2015. A Review on Chenopodium botrys L.: traditional uses, chemical composition and biological activities. Pharm. Biomed. Res. 1, 1-9.

Nikolova, M., Evstatieva, L., Nguyen, T.D., 2011. Screening of plant extracts for antioxidant properties. Botanica Serbica $35,43-48$.

Nowak, R., Szewczyk, K., Gawlik-Dziki, U., Rzymowska, J., Komsta, L., 2015. Antioxidative and cytotoxic potential of some Chenopodium L. species growing in Poland. Saudi J. Biol. Sci. 23, 15-23.

Paśko, P., Sajewicz, M., Gorinstein, S., Zachwieja, Z., 2008. Analysis of selected phenolic acids and flavonoids in Amaranthus cruentus and Chenopodium quinoa seeds and sprouts by HPLC. Acta Chromatogr. 20, 661-672.

Penarrieta, J.M., Alvarado, J.A., Akesson, B., Bergenstahl, B., 2008. Total antioxidant capacity and content of flavonoids and other phenolic compounds in canihua (Chenopodium pallidicaule): An Andean pseudocereal. Mol. Nutr. Food Res. 52, 708-717.

Seidemann, J., 2005. World Spice Plants: Economic Usage, Botany, Taxonomy. Berlin Heidelberg: Springer, VIII, 592593.

Serteser, A., Kargioglu, M., Gok, V., Bagci, Y., Ozcan, M.M., Arslan, D., 2009. Antioxidant properties of some plants growing wild in Turkey. Grasas Y Aceites 60, 147-154.

Shahat, A.A., Ibrahim, A.Y., Hendawy, S.F., Omer, E.A., Hammouda, F.M., Abdel-Rahman, F.H., Saleh, M.A., 2011. Chemical composition, antimicrobial and antioxidant activities of essential oils from organically cultivated fennel cultivars. Molecules 16, 1366-1377. 
Shikov, A.N., Poltanov, E.A., Dorman, H.D., Makarov, V.G., Tikhonov, V.P., Hiltunen, R., 2006. Chemical composition and in vitro antioxidant evaluation of commercial watersoluble willow herb (Epilobium angustifolium L.) extracts. J. Agric. Food Chem. 54, 3617-3624.

Singleton, V.L., Orthofer, R., Lamuela-Raventos, R.M., 1999. Analysis of total phenols and other oxidation substrates and antioxidants by means of folin-ciocalteu reagent. Methods Enzymol. 299, 152-178.
Stankovic, M., 2011. Total phenolic content, flavonoid concentration and antioxidant activity of Marrubium peregrinum L. Extracts. Kragujevac J. Sci. 33, 63-72.

Wojdylo, A., Oszmianski. J., Czemerys, R., 2007. Antioxidant activity and phenolic compounds in 32 selected herbs. Food Chem. 105, 940-949.

Yadav, N., Vasudeva, N., Singh, S., Sharma, S.K., 2007. Medicinal properties of genus Chenopodium Linn. Nat. Prod. Rad. 6, 131-134.

\title{
Антиоксидативен потенцијал на Chenopodium botrys L. (Amaranthaceae)
}

\author{
Љубица Аџи Андов ${ }^{1 *}$, Марија Карапанџова ${ }^{1}$, Благица Јованова ${ }^{2}$, Ѓше Стефков ${ }^{1}$, \\ Ивана Цветковиќ Каранфилова ${ }^{1}$, Татјана Кадифкова Пановска ${ }^{2}$ \\ и Светлана Кулеванова ${ }^{1}$
}

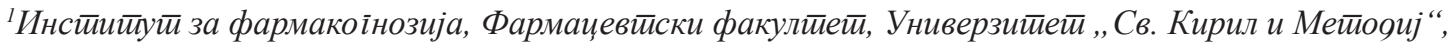 \\ Мајка Тереза 47, 1000 Скойје, Рейублика Макеоонија

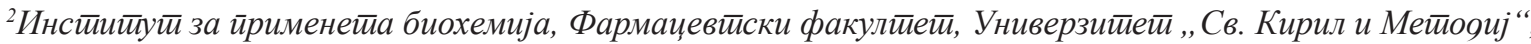 \\ Мајка Тереза 47, 1000 Скойје, Рейублика Макеоонија
}

Клучни зборови: Chenopodium botrys, вкупни флавоноиди, вкупни полифеноли, антиоксидативна активност, DPPH, NSSOH, SSOH, FRAP, инхибиција на $\mathrm{H}_{2} \mathrm{O}_{2}$.

Направена е евалуација на антиоксидативниот потенцијал на метанолен екстракт од Chenopodium botrys L. (Amaranthaceae) собран од шест различни локации во Република Македонија. За таа цел користени се неколку методи за тестирање на антиоксидативната активност: 1) тест за определување на способноста за неутрализација на слободни радикали (DPPH); 2) тест за определување на фери редуцирачки антиоксидативен капацитет (FRAP); 3) тест за определување на неутрализирачкиот капацитет врз $\mathrm{H}_{2} \mathrm{O}_{2}$; 4) неспецифичен хидроксирадикал посредуван 2-деокси-D-рибоза тест (NSSOH); и 5) специфичен хидроксирадикал посредуван 2-деокси-D-рибоза тест (SSOH). Вредностите за $\mathrm{IC}_{50}$ се движт од 0,26-3,10 mg/mL, 3,01-12,71 mg/mL и 2,60-12,29 mg/mL, за DPPH, NSSOH и SSOH тестовите, соодветно. Инхибиторната активност на $\mathrm{H}_{2} \mathrm{O}_{2}$ и фери-редуцирачката моќност се движат од 28,84-46,56\% и 26,14-43,40\%, соодветно. Добиените податоци покажуваат концентрациски зависен антиоксидативен потенцијал. Дополнитено, беше утврдена и содржината на вкупните полифеноли (ТРС) и вкупните флавоноиди (TFC). Определените вредности се: 27,77-71,25 mg GAE/g на сува маса за вкупни полифеноли и 7,35-16,33 mg QE/g на сува маса за вкупни флавоноиди. 